\title{
Presence of glutamine:fructose-6-phosphate amidotransferase for glucosamine-6-phosphate synthesis in endothelial cells: effects of hyperglycaemia and glutamine
}

\author{
G.Wu' ${ }^{1}$, T.E.Haynes ${ }^{1}$, W. Yan $^{1}$, C.J.Meininger ${ }^{2}$ \\ ${ }^{1}$ Department of Animal Science and Faculty of Nutrition, Texas A \& M University, College Station, Texas, USA \\ ${ }^{2}$ Cardiovascular Research Institute and Department of Medical Physiology, Texas, USA \\ The Texas A \& M University System Health Science Center, College Station, Texas, USA
}

\section{Abstract}

Aims/hypothesis. Recent studies show that glucosamine infusion impairs endothelium-dependent blood flow in normoglycaemic rats. The pathophysiological relevance of this finding, however, depends on whether de novo glucosamine synthesis occurs in endothelial cells. The aim of this study was to test the hypothesis of whether glutamine:fructose-6-phosphate amidotransferase (the first and key regulatory enzyme in hexosamine synthesis) is present for endothelial glucosamine synthesis.

Methods. Bovine venular, bovine aortic, human microvascular, human umbilical vein, and rat coronary microvascular endothelial cells were used to measure glutamine:fructose-6-phosphate amidotransferase activity. To determine glucosamine-6-phosphate synthesis in intact cells, they were incubated for $1 \mathrm{~h}$ in Krebs bicarbonate buffer containing 5,15 or $30 \mathrm{mmol} / \mathrm{l}$ $\left[\mathrm{U}-{ }^{14} \mathrm{C}\right]$ glucose and $0.5,2$ or $4 \mathrm{mmol} / \mathrm{l}$ glutamine. The $\left[{ }^{14} \mathrm{C}\right]$ Glucosamine-6-phosphate and its end products $\left(\left[{ }^{14} \mathrm{C}\right] \mathrm{UDP}-\mathrm{N}\right.$-acetylglucosamine and $\left[{ }^{14} \mathrm{C}\right] \mathrm{UDP}-\mathrm{N}$ acetylgalactosamine) were separated by HPLC.
Results. There were high glutamine:fructose-6-phosphate amidotransferase activities in all endothelial cells studied. Exposure of cells to 15 to $30 \mathrm{mmol} / \mathrm{l} \mathrm{glu}-$ cose or 2 to $4 \mathrm{mmol} / \mathrm{l}$ glutamine increased enzyme activity. Glucosamine-6-phosphate, UDP- $N$-acetylglucosamine and UDP- $N$-acetylgalactosamine syntheses increased with increasing extracellular concentrations of glucose from 5 to $30 \mathrm{mmol} / \mathrm{l}$ or of glutamine from 0.5 to $4 \mathrm{mmol} / \mathrm{l}$.

Conclusion/interpretation. Our results show the presence of glutamine:fructose-6-phosphate amidotransferase for de novo glucosamine synthesis in endothelial cells and the modulation of this pathway by hyperglycaemia and glutamine. As glucosamine inhibits endothelial nitric oxide synthesis, these findings could have important implications for impaired endothelium-dependent relaxation and vascular dysfunction in diabetes mellitus. [Diabetologia (2001) 44: 196-202]

Keywords Glucosamine-6-phosphate, hyperglycaemia, glutamine, endothelial cells.
Received: 19 June 2000 and in revised form: 6 October 2000

Corresponding author: Dr. G. Wu, 212 Kleberg Center, Department of Animal Science, Texas A \& M University, 2471 TAMUS, College Station, Texas, USA 77843-2471

Abbreviations: EC, Endothelial cells; ECGF, endothelial cell growth factor; GFAT, glutamine:fructose-6-phosphate amidotransferase; glucosamine-6-P, glucosamine-6-phosphate; UDP-GlcNAc, UDP- $N$-acetylglucosamine; UDP-GalNAc, UDP- $N$-acetylgalactosamine; UDP, uridine diphosphate; UTP, uridine triphosphate; SNK, Student-Newman-Keuls
Glucosamine-6-phosphate (glucosamine-6-P) is synthesized from L-glutamine and D-fructose-6-P (produced from glucose via glycolysis) in humans and animals [1]. Glucosamine:fructose-6-P amidotransferase (GFAT) catalyses the first and rate-controlling step in the synthesis of UDP- $N$-acetylglucosamine (UDP-GlcNAc) (Fig.1), a precursor for the formation of all macromolecules containing amino sugars [1]. This enzyme is known to be present in the liver, adipose tissue, smooth muscle, kidney, heart and skeletal muscle [2-6]. An increase in hexosamine biosynthesis has been shown to impair glucose utilization 


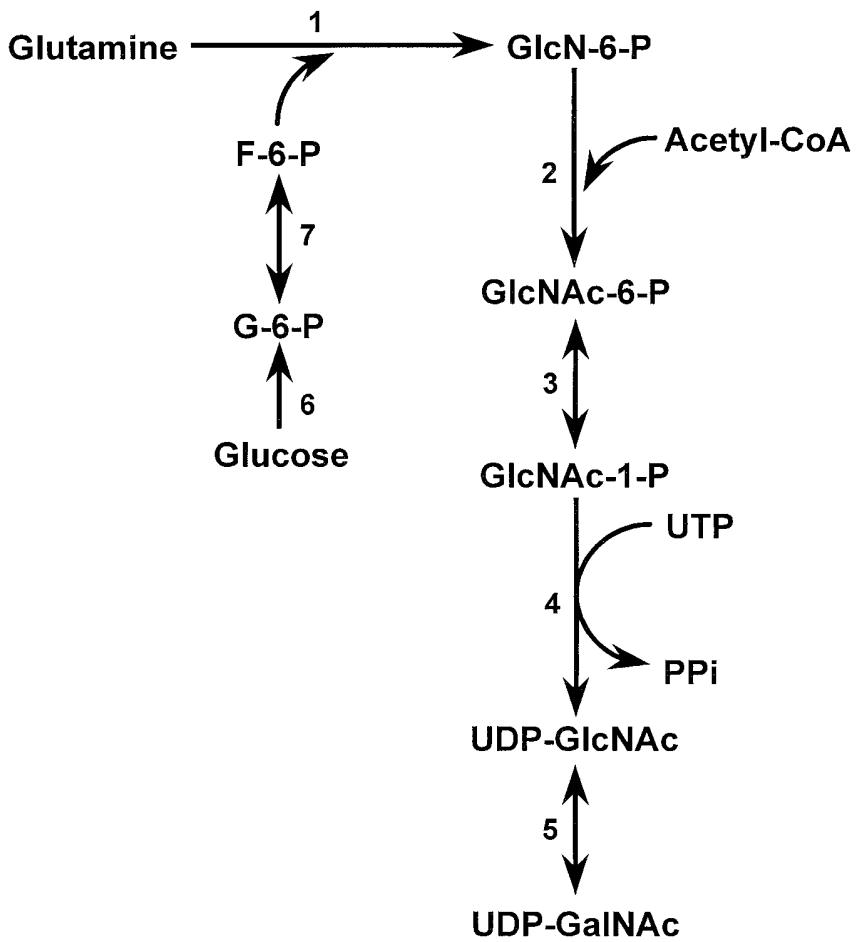

Fig. 1. Pathway of glucosamine synthesis in endothelial cells. Enzymes that catalyse the indicated reactions are: 1, glutamine:fructose-6-P amidotransferase; 2, glucosaminephosphate $N$-acetyltransferase; 3 , phosphoacetylglucosamine mutase; 4, UDP- $N$-acetyl-glucosamine pyrophosphorylase; 5 , UDP- $N$-acetylglucosamine 4-epimerase; 6, hexokinase; 7, phosphohexose isomerase

by insulin-sensitive tissues (such as skeletal muscle and adipose tissue) [7-15]. Thus, there has been growing interest in a role for glucosamine in mediating insulin resistance in diabetes mellitus $[14,15]$. It was recently reported that intravenous infusion of glucosamine, which enters cells via glucose transporters for conversion into glucosamine-6-P, considerably reduced blood flow in hind limb femoral muscles of normoglycaemic rats [16]. Similarly, increased concentrations of glutamine and glucose inhibit nitric oxide synthesis in endothelial cells and impair endothelium-dependent relaxation [17-20]. These findings suggest that glucosamine or its precursors affect endothelial cell function and raise an important question of whether increased glucosamine synthesis from glutamine and glucose mediates impaired endothelium-dependent relaxation in diabetes.

Glucosamine:fructose-6-P amidotransferase activity or expression has not been reported for endothelial cells. On the basis of immunohistochemical staining, GFAT was thought to be absent from human endothelium [5]. Identifying the presence of GFAT in endothelial cells is therefore necessary to clarify the role for the hexosamine-synthetic pathway in endothelial dysfunction in diabetes. In the light of our recent finding that glutamine metabolism via a hex- osamine-synthetic pathway is necessary for glutamine inhibition of nitric oxide synthesis in endothelial cells [21], we hypothesized that GFAT is present for glucosamine-6-P synthesis in these cells.

\section{Materials and methods}

Chemicals. L-Glutamine, D-glucose, HEPES, bovine serum albumin (BSA, essentially fatty-acid free), NADH, EDTA, dithiothreitol, D-glucosamine-6-P, D-fructose-6-P, D-glucose-6-P, phenylmethylsulphonyl fluoride, aprotinin, chymostatin and pepstatin A were obtained from Sigma Chemicals (St. Louis, Mo., USA). The L-[U- $\left.{ }^{14} \mathrm{C}\right]$ Glutamine, L- $\left[\mathrm{U}-{ }^{14} \mathrm{C}\right]$ glutamate, D$\left[\mathrm{U}-{ }^{14} \mathrm{C}\right]$ glucose, and [glucose- $\left.{ }^{14} \mathrm{C}\right] \mathrm{UDP}-\mathrm{GlcN}$ Ac were obtained from American Radiolabeled Chemicals (St. Louis, Mo., USA). The [Galactosamine- $\left.1-{ }^{3} \mathrm{H}(\mathrm{N})\right]-U D P-N$-acetyl-D-galactosamine (UDP-GalNAc) was purchased from New England Nuclear (Boston, Mass., USA). Calcium-free and magnesiumfree Dulbecco's phosphate-buffered saline and Dulbecco's modified Eagle's medium (DMEM) were obtained from Gibco-BRL (Grand Island, N. Y., USA). Fetal bovine serum was obtained from Summit (Greeley, Colo., USA). Endothelial cell growth factor (ECGF) was obtained from Biomedical Technologies (Stoughton, Mass., USA).

Isolation and culture of endothelial cells. Bovine venular and bovine aortic endothelial cells were isolated from coronary venules $(15 \mu \mathrm{m}$ in diameter) and aorta of adult cattle, respectively, as described previously $[18,22]$. Human microvascular endothelial cells were isolated from a mesentery segment of an adult human for non-neoplastic bowel obstruction [22]. Rat coronary microvascular endothelial cells were isolated from the hearts of Sprague-Dawley rats (300-325 g), as described previously [23]. The endothelial identity was confirmed by positive staining for factor VIII-related antigen and uptake of modified low-density lipoprotein [22, 23]. Human umbilical vein endothelial cells were obtained from Clonetics (San Diego, Calif., USA). Endothelial cells were cultured in DMEM containing ECGF $(100 \mu \mathrm{g} / \mathrm{ml}), 10 \mathrm{mmol} / \mathrm{l} \mathrm{D}$-glucose, $1 \mathrm{mmol} / \mathrm{l} \mathrm{L}$-glutamine, $1 \mathrm{mmol} / \mathrm{l}$ sodium pyruvate, $100 \mathrm{units} / \mathrm{ml}$ penicillin, $100 \mu \mathrm{g} / \mathrm{ml}$ streptomycin and $0.25 \mu \mathrm{g} / \mathrm{ml}$ amphotericin B. After cells neared confluence, ECGF was replaced with $20 \%$ fetal bovine serum. Cell lines were passaged by trypsinization in Dulbecco's phosphate-buffered saline containing $0.25 \%$ trypsin and $0.02 \%$ EDTA. Endothelial cells at passages 9-12 were used for GFAT assay and metabolic studies.

Determination of GFAT activity. We determined GFAT activity as described by other investigators [10] with modifications. Endothelial cells $\left(5 \times 10^{6}\right)$ were suspended in $0.5 \mathrm{ml}$ of $50 \mathrm{mmol} / \mathrm{l}$ sodium phosphate buffer ( $\mathrm{pH} 7.5$ ) containing $100 \mathrm{mmol} / \mathrm{l} \mathrm{KCl}$, $1 \mathrm{mmol} / \mathrm{l}$ EDTA, $2.5 \mathrm{mmol} / \mathrm{l}$ dithiothreitol, 0 or $12 \mathrm{mmol} / \mathrm{l} \mathrm{D}$ glucose-6-P, a stabilizer of GFAT [2], and protease inhibitors $(5 \mu \mathrm{g} / \mathrm{ml}$ phenylmethylsulphonyl fluoride, $5 \mu \mathrm{g} / \mathrm{ml}$ aprotinin, $5 \mu \mathrm{g} / \mathrm{ml}$ chymostatin, $5 \mu \mathrm{g} / \mathrm{ml}$ pepstatin A). Cells were lysed by three cycles of freezing (liquid nitrogen) and thawing $\left(37^{\circ} \mathrm{C}\right)$. Cell lysates were centrifuged at $10000 \mathrm{~g}$ and $4{ }^{\circ} \mathrm{C}$ for $1 \mathrm{~min}$ and the supernatant was used for enzyme assay. The assay mixture $(0.1 \mathrm{ml})$ consisted of $12 \mathrm{mmol} / \mathrm{l} \mathrm{L}$-glutamine, $12 \mathrm{mmol} / \mathrm{l}$ D-fructose-6-P, 0 or $12 \mathrm{mmol} / \mathrm{l}$ D-glucose-6-P, $1 \mathrm{mmol} / \mathrm{l}$ EDTA, $1 \mathrm{mmol} / 1$ dithiothreitol and cell extracts (0.1-0.3 mg protein) and was incubated at $37^{\circ} \mathrm{C}$ for $0,15,30$ and $45 \mathrm{~min}$. The reaction was terminated by addition of $50 \mu \mathrm{l}$ of $1.5 \mathrm{~mol} / 1 \mathrm{HClO}_{4}$, and the acidified solution was neutralized with $25 \mu \mathrm{l}$ of $2 \mathrm{~mol} / 1 \mathrm{~K}_{2} \mathrm{CO}_{3}$. The neutralized extracts were di- 
luted 20 times with HPLC $\mathrm{H}_{2} \mathrm{O}$ before use for glucosamine-6-P analysis. Glucosamine-6-P was separated by an HPLC method involving precolumn derivatization with $o$-phthaldialdehyde, as well as Solvent A $(0.1 \mathrm{~mol} / \mathrm{l}$ sodium acetate, $0.5 \%$ tetrahydrofuran, $9 \%$ methanol, $\mathrm{pH} 7.2$ ) and Solvent B (methanol) [22]. The gradient used for glucosamine-6-P analysis was as follows: at $0 \mathrm{~min}, 86 \% \mathrm{~A}$ and $14 \% \mathrm{~B}$; at $14 \mathrm{~min}, 86 \% \mathrm{~A}$ and $14 \%$ $\mathrm{B}$; at $14.1 \mathrm{~min}, 0 \% \mathrm{~A}$ and $100 \% \mathrm{~B}$; at $18 \mathrm{~min}, 0 \% \mathrm{~A}$ and $100 \%$ $\mathrm{B}$; at $18.1 \mathrm{~min}, 86 \% \mathrm{~A}$ and $14 \% \mathrm{~B}$ and at $24.5 \mathrm{~min}, 86 \% \mathrm{~A}$ and $14 \% \mathrm{~B}$. The retention time of glucosamine-6-P was $8.24 \mathrm{~min}$, as identified with an authentic glucosamine-6-P standard. In the GFAT assay, enzyme activity was linear with time (up to $45 \mathrm{~min})$ and cell protein $(0.05-0.5 \mathrm{mg})$.

Glucosamine-6-P and UDP-GlcNAc synthesis. To improve the sensitivity for detecting the synthesis of glucosamine-6-P, UDP-GlcNAc and UDP-GalNAC (the product of UDP-GlcNAc's 4-epimeration) in intact endothelial cells, we used a radiochemical technique. Endothelial cells $\left(10 \times 10^{6}\right)$ were incubated for $1 \mathrm{~h}$ in $2 \mathrm{ml} \mathrm{KHB}$ buffer ( $\mathrm{pH} \mathrm{7.4)} \mathrm{containing} 1 \%$ BSA, $5 \mathrm{mmol} / \mathrm{l}$ D-[U- $\left.{ }^{14} \mathrm{C}\right]$ glucose $(450 \mathrm{dpm} / \mathrm{nmol})$ and $2 \mathrm{mmol} / \mathrm{l} \mathrm{L}$-glutamine. Blank media containing all components but no cells were run in parallel. Incubations were terminated by adding $0.2 \mathrm{ml}$ of $1.5 \mathrm{~mol} / 1 \mathrm{HClO}_{4}$ and the acidified media were neutralized with $0.1 \mathrm{ml}$ of $2 \mathrm{~mol} / 1 \mathrm{~K}_{2} \mathrm{CO}_{3}$. Neutralized extracts were freeze-dried and suspended in $0.3 \mathrm{ml} \mathrm{HPLC} \mathrm{H}_{2} \mathrm{O}$ for analysis of ${ }^{14} \mathrm{C}$-labelled glucosamine6-P, UDP-GlcNAc and UDP-GalNAc. The $\left[{ }^{14} \mathrm{C}\right] \mathrm{Glu}-$ cosamine-6-P was separated by HPLC as described above; the fraction containing $\left[{ }^{14} \mathrm{C}\right]$ glucosamine-6-P was collected from the HPLC column and radioactivity measured using a liquid scintillation counter. For $\left[{ }^{14} \mathrm{C}\right]$ UDP-GlcNAc and $\left[{ }^{14} \mathrm{C}\right]$ UDP-GalNAc evaluation, each neutralized sample was desalted using a 1-ml $\mathrm{C}_{18}$ Sep-Pak cartridge (Waters, Milford, Mass., USA), and then applied to a Partisil-10 SAX column $(4.6 \times 250 \mathrm{~mm})$ (Phenomenex Inc., Torrance, Calif., USA). The $\left[{ }^{14} \mathrm{C}\right]$ UDP-GlcNAc and $\left[{ }^{14} \mathrm{C}\right]$ UDP-GalNAc were separated by an isocratic, anion-exchange HPLC system using borate buffer, as described [24]. The fractions containing $\left[{ }^{14} \mathrm{C}\right]$ UDP-GlcNAc and $\left[{ }^{14} \mathrm{C}\right]$ UDP-GalNAc were collected from the HPLC column and radioactivities measured using a liquid scintillation counter. Retention times for UDP-GlcNAc and UDP-GalNAc were 10.8 and $17.4 \mathrm{~min}$, respectively, as identified with authentic $\left[{ }^{14} \mathrm{C}\right]$ UDP-GlcNAc and $\left[{ }^{3} \mathrm{H}\right]$ UDP-GalNAc standards.

Effect of hyperglycaemia and glutamine on glucosamine-6-P and UDP-GlcNAc synthesis. Rat coronary microvascular and bovine venular endothelial cells were used to evaluate the effect of increased concentrations of glucose and glutamine on glucosamine-6-P and UDP-GlcNAc synthesis. Cell incubations were carried out as described above, with the exception that the incubation media contained 5,15 or $30 \mathrm{mmol} / \mathrm{l} \mathrm{D}-[\mathrm{U}$ $\left.{ }^{14} \mathrm{C}\right]$ glucose $(450 \mathrm{dpm} / \mathrm{nmol})$ and $0.5,2$ or $4 \mathrm{mmol} / \mathrm{l}$ L-glutamine. These cells were used for this study because they were readily available in large amounts in our laboratories. The concentrations of glucose and glutamine were chosen on the basis of their plasma concentrations in diabetic patients or animals with poor metabolic control [25]. The $\left[{ }^{14} \mathrm{C}\right]$ Glucosamine-6-P, $\left[{ }^{14} \mathrm{C}\right]$ UDP-GlcNAc and $\left[{ }^{14} \mathrm{C}\right]$ UDP-GalNAc were evaluated by HPLC methods and liquid scintillation counter, as described above. Our preliminary studies showed that the production of $\left[{ }^{14} \mathrm{C}\right]$ glucosamine-6-P, $\left[{ }^{14} \mathrm{C}\right]$ UDP-GlcNAc and $\left[{ }^{14} \mathrm{C}\right]$ UDP-GalNAc by endothelial cells was linear during a 1-h incubation period in the presence of 5 to $30 \mathrm{mmol} / 1 \mathrm{D}-\left[\mathrm{U}^{-14} \mathrm{C}\right]$ glucose and 0.5 to $4 \mathrm{mmol} / \mathrm{l} \mathrm{L}$-glutamine.
Effect of hyperglycaemia and glutamine on GFAT activity. Because our preliminary study indicated that rat coronary microvascular endothelial cells and bovine venular endothelial cells responded similarly to increased concentrations of glucose and glutamine with glucosamine-6-P synthesis from glutamine and glucose, rat coronary microvascular endothelial cells were chosen to study the effect of hyperglycaemia and glutamine on GFAT activity. Freshly isolated rat coronary endothelial cells were cultured as described above, except that culture media contained 5,15 or $30 \mathrm{mmol} / \mathrm{l}$ glucose in the presence of $0.5,2$ or $4 \mathrm{mmol} / \mathrm{l} \mathrm{L}$-glutamine. Conditioned media were replaced daily with fresh media. After a 7-day culture period, cells were obtained for determining GFAT activity, as described above.

GFAT activity in freshly isolated endothelial cells and tissues. Coronary microvascular endothelial cells were isolated from Sprague-Dawley rats (300-325 g) as described previously [23]. Cells were used immediately for measuring GFAT activity as described above. Epididymal fat, gastrocnemius muscle and heart were also obtained from the rats for measuring tissue GFAT activities. Tissues $(0.5 \mathrm{~g})$ were homogenized in a glass homogenizer with $2 \mathrm{ml}$ of $50 \mathrm{mmol} / \mathrm{l}$ sodium phosphate buffer (pH 7.5) containing $100 \mathrm{mmol} / \mathrm{l} \mathrm{KCl}, 1 \mathrm{mmol} / \mathrm{l}$ EDTA, $2.5 \mathrm{mmol} / \mathrm{l}$ dithiothreitol, 0 or $12 \mathrm{mmol} / \mathrm{l} \mathrm{D}$-glucose- $6-\mathrm{P}$, and protease inhibitors $(5 \mu \mathrm{g} / \mathrm{ml}$ phenylmethyl-sulphonyl fluoride, $5 \mu \mathrm{g} / \mathrm{ml}$ aprotinin, $5 \mu \mathrm{g} / \mathrm{ml}$ chymostatin, $5 \mu \mathrm{g} / \mathrm{ml}$ pepstatin A). Homogenates were centrifuged at $10000 \mathrm{~g}$ and $4^{\circ} \mathrm{C}$ for $1 \mathrm{~min}$ and the supernatant was used for GFAT assay in the presence or absence of $12 \mathrm{mmol} / \mathrm{l} \mathrm{D}$-glucose-6-P, as described above. The GFAT assay conditions used allow for comparison of tissue GFAT activities between this study and previous studies involving either the presence or absence of $12 \mathrm{mmol} / \mathrm{l} \mathrm{D}$-glucose6-P $[11,26]$.

Statistical analyses. Results were statistically analysed by twoway analysis of variance with the Student-Newman-Keuls (SNK) multiple range test or by paired $t$ - test [27]. We considered $p$ values of less than 0.05 to indicate statistical significance.

\section{Results}

Activities of GFAT in cultured endothelial cells. Bovine venular, bovine aortic, human microvascular, human umbilical vein and rat coronary microvascular endothelial cells contained high activities of GFAT (Fig.2). As reported for other cell types, including hepatocytes, brain and muscle [2], we found that the inclusion of $12 \mathrm{mmol} / \mathrm{l}$ glucose-6$\mathrm{P}$ in the cell homogenization medium and enzyme assay mixture increased $(p<0.01)$ GFAT activity by about 53 to $56 \%$ in all endothelial cells studied (Fig. 2). The activities of GFAT were similar among the bovine, rat and human endothelial cells studied (Fig. 2).

Glucosamine-6-P and UDP-GlcNAc synthesis in cultured endothelial cells. All endothelial cells studied were capable of synthesizing glucosamine-6-P, UDPGlcNAc and UDP-GalNAc from glutamine and glucose (Table 1). Because glucosamine-6-P was further 


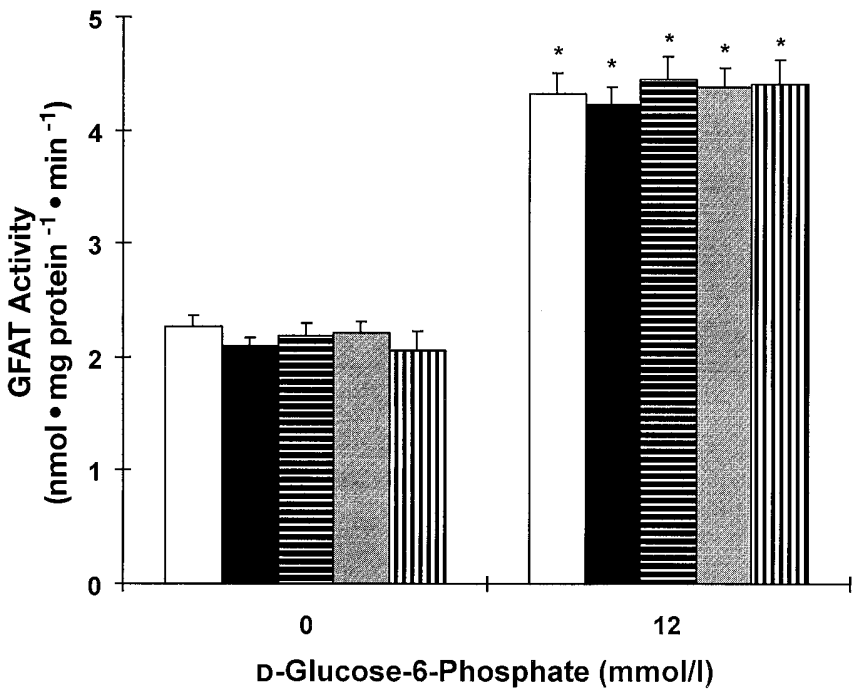

Fig. 2. Glutamine:fructose-6-phosphate amidotransferase (GFAT) activity in bovine, rat and human endothelial cells. Data are means \pm SEM, $n=8$, and were analysed by paired $t$ test. Endothelial cells were cultured in the presence of $10 \mathrm{mmol} / \mathrm{l} \mathrm{D}$-glucose and $1 \mathrm{mmol} / \mathrm{l} \mathrm{L}$-glutamine. Confluent cells were used for homogenization and GFAT assay in the presence of 0 or $12 \mathrm{mmol} / \mathrm{l} \mathrm{D}$-glucose-6-phosphate, as described in the text. ${ }^{*} p<0.01$ vs the $0 \mathrm{mmol} / 1 \mathrm{D}$-glucose-6-phosphate group, $\square$ Bovine venular EC; $\square$ Bovine aortic EC; 囬 Human microvascular EC; 圈 Human umbilical vein EC; 而 Rat coronary microvascular EC

metabolized to UDP-GlcNAc (Fig.1), the amount of glucosamine-6-P measured at the end of the 1-h incubation period represents its net accumulation in endothelial cells. On the basis of the utilization of glutamine $\left(250 \mathrm{nmol} \cdot 10^{6} \mathrm{cells}^{-1} \cdot \mathrm{h}^{-1}\right.$ in the presence of $2 \mathrm{mmol} / \mathrm{l}$ glutamine $)$ and glucose $\left(60 \mathrm{nmol} \cdot 10^{6}\right.$ cells $^{-1}$ $\cdot \mathrm{h}^{-1}$; in the presence of $5 \mathrm{mmol} / \mathrm{l}$ glucose) by endothelial cells $[28,29]$, production of total UDP-GlcNAc (based on net accumulation of UDP-GlcNAc plus UDP-GalNAc) accounted for approximately 0.3 and $1.5 \%$ of the glutamine and glucose metabolized by endothelial cells, respectively. There was no synthesis of $\left[{ }^{14} \mathrm{C}\right]$ glucosamine-6-P, $\quad\left[{ }^{14} \mathrm{C}\right]$ UDP-GlcNAc or $\left[{ }^{14} \mathrm{C}\right]$ UDP-GalNAC in endothelial cells incubated in the presence of 5,15 or $30 \mathrm{mmol} / \mathrm{l} \mathrm{D}-\left[\mathrm{U}_{-}{ }^{14} \mathrm{C}\right]$ glucose but the absence of L-glutamine in the incubation medium.
Table 2. Effects of glucose and glutamine on glucosamine-6phosphate, UDP- $N$-acetylglucosamine and UDP- $N$-acetylgalactosamine synthesis in rat coronary microvascular endothelial cells

\begin{tabular}{|c|c|c|c|}
\hline \multirow{2}{*}{$\begin{array}{l}\text { Medium glut- } \\
\text { amine concen- } \\
\text { trations } \\
(\mathrm{mmol} / \mathrm{l})\end{array}$} & \multicolumn{3}{|c|}{ Medium glucose concentrations (mmol/l) } \\
\hline & 5 & 15 & 30 \\
\hline & \multicolumn{3}{|c|}{ Glucosamine-6-phosphate } \\
\hline 0.5 & $0.87 \pm 0.08^{\mathrm{c}}$ & $4.37 \pm 0.39^{\mathrm{b}}$ & $7.83 \pm 0.68^{\mathrm{a}}$ \\
\hline 2 & $2.61 \pm 0.25^{\mathrm{cd}}$ & $17.7 \pm 1.2^{\text {bd }}$ & $30.3 \pm 2.6^{\mathrm{ad}}$ \\
\hline 4 & $3.94 \pm 0.33^{\text {ce }}$ & $25.6 \pm 2.2^{\text {be }}$ & $42.7 \pm 3.5^{\mathrm{ae}}$ \\
\hline $\begin{array}{l}0.5 \\
2 \\
4\end{array}$ & $\begin{array}{l}\text { UDP- } N \text {-Ace } \\
0.19 \pm 0.02^{\mathrm{c}} \\
0.56 \pm 0.07^{\mathrm{cd}} \\
0.78 \pm 0.09^{\mathrm{ce}}\end{array}$ & $\begin{array}{l}\text { lucosamine } \\
0.86 \pm 0.07^{\mathrm{b}} \\
2.94 \pm 0.23^{\mathrm{bd}} \\
3.91 \pm 0.36^{\mathrm{be}}\end{array}$ & $\begin{array}{l}1.51 \pm 1.2^{\mathrm{a}} \\
5.54 \pm 0.53^{\mathrm{ad}} \\
7.38 \pm 0.68^{\mathrm{ae}}\end{array}$ \\
\hline $\begin{array}{l}0.5 \\
2 \\
4\end{array}$ & $\begin{array}{l}\text { UDP- } N \text {-Ace } \\
0.06 \pm 0.01^{\mathrm{c}} \\
0.17 \pm 0.02^{\text {cd }} \\
0.24 \pm 0.02^{\text {ce }}\end{array}$ & $\begin{array}{c}\text { alactosamine } \\
0.27 \pm 0.02^{\mathrm{b}} \\
0.80 \pm 0.06^{\mathrm{bd}} \\
1.29 \pm 0.10^{\mathrm{be}}\end{array}$ & $\begin{array}{l}0.42 \pm 0.04^{\mathrm{a}} \\
1.33 \pm 0.12^{\mathrm{ad}} \\
2.05 \pm 0.18^{\mathrm{ae}}\end{array}$ \\
\hline
\end{tabular}

Data are means \pm SEM, $n=8$; in nmol $\cdot 10^{6}$ cells $^{-1} \cdot \mathrm{h}^{-1}$ for UDP-GlcNAc and UDP-GalNAc and in pmol $\cdot 10^{6}$ cells $^{-1}$. $\mathrm{h}^{-1}$ for glucosamine-6-P. Data were analysed by two-way ANOVA and the SNK test. Rat coronary microvascular endothelial cells were incubated at $37^{\circ} \mathrm{C}$ for $1 \mathrm{~h}$ in $2.0 \mathrm{ml} \mathrm{KHB}$ buffer (pH 7.4) containing 5, 15 or $30 \mathrm{mmol} / \mathrm{l} \mathrm{D}-\left[\mathrm{U}-{ }^{14} \mathrm{C}\right]$ glucose and $0.5,2$ or $4 \mathrm{mmol} / \mathrm{l} \mathrm{L}$-glutamine

${ }^{\mathrm{a}-\mathrm{c}}$ : Means displaying different letters $(\mathrm{a}, \mathrm{b}, \mathrm{c})$ within a row are different $(p<0.01)$

d $p<0.01$ vs the 0.5 and $4 \mathrm{mmol} / 1 \mathrm{~L}$-glutamine groups

${ }^{\mathrm{e}} p<0.05$ vs the $2 \mathrm{mmol} / \mathrm{l} \mathrm{L-glutamine}$ group

\begin{abstract}
Modulation of glucosamine-6-P and UDP-GlcNAc synthesis by hyperglycaemia and glutamine in cultured endothelial cells. In rat coronary microvascular endothelial cells, glucosamine-6-P, UDP-GlcNAc and UDP-GINAc synthesis increased $(p<0.01)$ with increasing extracellular glucose concentration from 5 to $30 \mathrm{mmol} / \mathrm{l}$ in the presence of $0.5,2$ or $4 \mathrm{mmol} / 1$ glutamine (Table 2). Glucosamine-6-P, UDP-GlcNAc and UDP-GalNAc synthesis also increased $(p<0.01)$ with increasing extracellular glutamine concentration from 0.5 to $4 \mathrm{mmol} / \mathrm{l}$ in the presence of 5,15 or $30 \mathrm{mmol} / \mathrm{l} \mathrm{D}-$ glucose in rat coronary microvascular endothelial cells (Table 2). Similar results on the effect of hyperglycaemia and glutamine on glucosamine-6-P, UDP-GlcNAc and UDP-GalNAc synthesis were obtained for bovine venular endothelial cells (data not shown).
\end{abstract}

Table 1. Glucosamine-6-phosphate, UDP- $N$-acetylglucosamine and UDP- $N$-acetyl-galactosamine synthesis in bovine, rat and human endothelial cells

\begin{tabular}{llllll}
\hline Products & $\begin{array}{l}\text { Bovine } \\
\text { venular EC }\end{array}$ & $\begin{array}{l}\text { Bovine } \\
\text { aortic EC }\end{array}$ & $\begin{array}{l}\text { Human } \\
\text { microvascular EC }\end{array}$ & $\begin{array}{l}\text { Human } \\
\text { umbilical vein EC }\end{array}$ & $\begin{array}{l}\text { Rat coronary } \\
\text { microvascular EC }\end{array}$ \\
\hline Glucosamine-6-P & $2.84 \pm 0.18$ & $2.97 \pm 0.21$ & $3.06 \pm 0.25$ & $2.88 \pm 0.37$ & $3.15 \pm 0.23$ \\
UDP-GlcNAc & $0.58 \pm 0.07$ & $0.54 \pm 0.08$ & $0.61 \pm 0.07$ & $0.56 \pm 0.06$ & $0.66 \pm 0.08$ \\
UDP-GalNAc & $0.18 \pm 0.03$ & $0.17 \pm 0.02$ & $0.18 \pm 0.02$ & $0.17 \pm 0.03$ & $0.20 \pm 0.03$ \\
\hline
\end{tabular}

Data are means \pm SEM, $n=8$; in $\mathrm{nmol} \cdot 10^{6} \mathrm{cells}^{-1} \cdot \mathrm{h}^{-1}$ for UDP-GlcNAc and UDP-GalNAc and in pmol $\cdot 10^{6}$ cells $^{-1}$. $\mathrm{h}^{-1}$ for glucosamine-6-P. Data were analysed by one-way
ANOVA and the SNK test. Endothelial cells were incubated at $37^{\circ} \mathrm{C}$ for $1 \mathrm{~h}$ in $2.0 \mathrm{ml} \mathrm{KHB}$ buffer ( $\left.\mathrm{pH} 7.4\right)$ containing $5 \mathrm{mmol} / \mathrm{l} \mathrm{D}-\left[\mathrm{U}-{ }^{14} \mathrm{C}\right]$ glucose and $2 \mathrm{mmol} / \mathrm{l}$ glutamine 


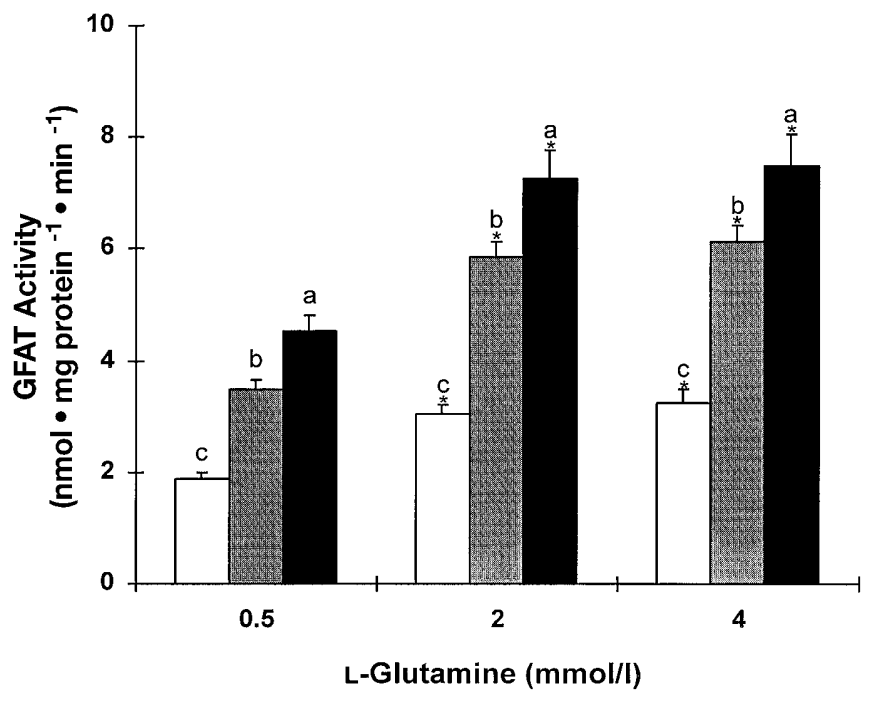

Fig.3. Effects of hyperglycaemia and glutamine on glutamine:fructose-6-phosphate amidotransferase (GFAT) activity in rat coronary microvascular endothelial cells. Data are means \pm SEM, $n=6$, and were analysed by two-way analysis of variance and the SNK test. Coronary microvascular endothelial cells freshly isolated from rat hearts were cultured in the presence of 5,15 or $30 \mathrm{mmol} / \mathrm{l} \mathrm{D}$-glucose and $0.5,2$ or $4 \mathrm{mmol} / \mathrm{l} \mathrm{L}$-glutamine. Confluent cells were used for homogenization and GFAT assay in the presence of $12 \mathrm{mmol} / \mathrm{l} \mathrm{D}$-glucose-6-phosphate, as described in the text. a-c: Means displaying different letters within each glutamine concentration are different $(p<0.01)$. ${ }^{*} p<0.01$ vs the $0.5 \mathrm{mmol} / 1 \mathrm{~L}$-glutamine group. $\square 5 \mathrm{mmol} / \mathrm{l}$ glucose, $15 \mathrm{mmol} / \mathrm{l}$ glucose, $\square 30 \mathrm{mmol} / \mathrm{l}$ glucose

Effects of hyperglycaemia and glutamine on GFAT activity in cultured endothelial cells. Increasing glucose concentrations in culture medium from 5 to $30 \mathrm{mmol} / \mathrm{l}$ in the presence of 0.5 or $2 \mathrm{mmol} / 1$ glutamine increased endothelial GFAT activity in a concentration-dependent manner. The greatest effect was observed when extracellular glucose concentrations increased from 5 to $15 \mathrm{mmol} / \mathrm{l}$. Similarly, increasing glutamine concentrations in culture medium from 0.5 to $2 \mathrm{mmol} / \mathrm{l}$ in the presence of 5,15 or $30 \mathrm{mmol} / \mathrm{l}$ glucose increased $(p<0.01)$ GFAT activity in endothelial cells. The GFAT activity did not increase further $(p>0.05)$ when extracellular glutamine concentrations increased from 2 to $4 \mathrm{mmol} / \mathrm{l}$ (Fig. 3).

GFAT activity in freshly isolated endothelial cells and insulin-sensitive tissues. Glutamine: fructose-6-phosphate aminotransferase activity was present in freshly isolated endothelial cells, which represents about $4.6 \%$ of GFAT activity in cultured endothelial cells (Fig. 2). It is noteworthy that GFAT activity in freshly isolated endothelial cells was $43 \%$ greater $(p<0.01)$ than that in epididymal fat and $470 \%$ greater than that in gastrocnemius muscle and heart (Table 3 ).
Table 3. Glutamine:fructose-6-phosphate amidotransferase (GFAT) activities in freshly isolated coronary microvascular endothelial cells and tissues of rats

\begin{tabular}{|c|c|c|}
\hline \multirow[t]{2}{*}{ Rat cells or tissues } & \multicolumn{2}{|c|}{$\begin{array}{l}\text { Glucose-6-phosphate concen- } \\
\text { trations in GFAT assay medi- } \\
\text { um (mmol/l) }\end{array}$} \\
\hline & 0 & 12 \\
\hline Freshly isolated endothelial cells & $90.2 \pm 7.4^{\mathrm{a}}$ & $197 \pm 15^{\mathrm{da}}$ \\
\hline Epididymal fat & $66.4 \pm 5.2^{\mathrm{b}}$ & $138 \pm 11^{\mathrm{db}}$ \\
\hline Gastrocnemius muscle & $17.9 \pm 1.4^{\mathrm{c}}$ & $36.5 \pm 3.0^{\mathrm{dc}}$ \\
\hline Heart & $16.8 \pm 1.2^{\mathrm{c}}$ & $34.4 \pm 2.7^{\mathrm{dc}}$ \\
\hline
\end{tabular}

Data are means \pm SEM, $n=6$; in $\mathrm{pmol} \cdot \mathrm{mg} \operatorname{protein}^{-1} \cdot \mathrm{min}^{-1}$. Data were analysed by two-way analysis of variance and the SNK test. Freshly isolated rat coronary microvascular endothelial cells and rat tissues were used for GFAT assay in the presence of 0 or $12 \mathrm{mmol} / \mathrm{l}$ D-glucose-6-phosphate, as described in the text.

$\mathrm{a}-\mathrm{c}$ means sharing different letters $(\mathrm{a}, \mathrm{b}, \mathrm{c})$ within a column are different $(p<0.01)$.

${ }^{\mathrm{d}} p<0.01$ vs the $0 \mathrm{mmol} / \mathrm{l} \mathrm{D}$-glucose-6-phosphate group.

\section{Discussion}

The GFAT enzyme catalyses the first and rate-controlling step in hexosamine biosynthesis [1]. This enzyme has been shown to be present in liver, adipose tissue, heart and skeletal muscle [2-6] but was thought to be absent from the human endothelium [5]. Our results show the presence of GFAT activity in freshly isolated rat coronary microvascular endothelial cells, which was 43 to $470 \%$ greater than that in the insulin-sensitive tissues (adipose tissue, skeletal muscle and heart) examined. It is possible that the vascular component of skeletal muscle and heart provides a major portion of the GFAT activity measured in the tissue homogenates. Our values of tissue GFAT activities are similar to those reported by other investigators for rat epididymal fat, gastrocnemius muscle and heart $[11,26]$. For example, GFAT activities, measured in the absence of added glucose-6-P, averaged 62, 15 and 16 $\left(\mathrm{pmol} \cdot \mathrm{mg}\right.$ protein $\left.{ }^{-1} \cdot \mathrm{min}^{-1}\right)$, respectively, in rat epididymal fat, gastrocnemius muscle and heart have been reported [26]. Greater GFAT activities in these tissues (e.g. 32-38 $\mathrm{pmol} \cdot \mathrm{mg}$ protein $^{-1} \cdot \min$ for rat hindlimb muscles composing primarily of gastrocnemius muscle) were obtained when $12 \mathrm{mmol} / \mathrm{l}$ glucose6-P (a stabilizer of GFAT) was included in the enzyme assay solution [11]. These data on tissue GFAT activities indicate that the GFAT assay method used in our laboratory gave results similar to those reported from other laboratories.

Of note, we found that GFAT activities were particularly high in all cultured bovine, rat and human endothelial cells studied. For example, GFAT activities in cultured endothelial cells were about 10-times to 100-times those reported for freshly isolated endothelial cells and insulin-sentitive tissues and about 4 times those reported for incubated rat epididymal 
adipocytes [2-5]. The much greater GFAT activity in cultured endothelial cells compared with freshly isolated endothelial cells suggests that endothelial GFAT expression could be largely influenced by the state of cell differentiation and up-regulated under in vitro culture conditions. The factors responsible for the regulation of endothelial GFAT expression have not been identified. Nevertheless, our finding that all cultured endothelial cells studied contained high GFAT activity is striking and raises an important question about the presence and regulation of the endothelial glucosamine-6-P synthetic pathway.

Consistent with the presence of endothelial GFAT activity, results of this study indicate glucosamine-6-P synthesis from glutamine and glucose in all endothelial cells studied. Furthermore, we found that rates of the endothelial hexosamine synthesis increased with increasing extracellular concentrations of glucose from 5 to $30 \mathrm{mmol} / \mathrm{l}$ and of glutamine from 0.5 to $4 \mathrm{mmol} / \mathrm{l}$. In addition, increased concentrations of glucose (15 and $30 \mathrm{mmol} / \mathrm{l})$ or glutamine (2 and $4 \mathrm{mmol} / \mathrm{l}$ ) increased endothelial GFAT activity. Thus, hyperglycaemia and glutamine regulate endothelial glucosamine-6-P synthesis via at least two mechanisms: enhancing GFAT activity and increasing substrate concentrations for the enzyme. These findings could have important implications for patients with diabetes mellitus in poor metabolic control, who are associated with increased plasma concentrations of both glucose and glutamine [25]. Of note GFAT activity has been reported to be enhanced in skeletal muscle of patients with Type II (non-insulindependent) diabetes mellitus [30] and hexosamine synthesis has been shown to be increased in skeletal muscle and liver of diabetic rats [11]. Considering a recent report on two GFAT isozymes in mammalian tissues [31], it would be of great interest to determine which GFAT isozyme is present in endothelial cells and how its activity is regulated by hyperglycaemia and glutamine.

As in smooth muscle cells, skeletal muscle and adipocytes [2-5], glucosamine-6-P, UDP-GlcNAc and UDP-GalNAc are quantitatively minor products of endothelial glutamine and glucose metabolism, accounting for about $0.3 \%$ and $1.5 \%$ of the glutamine and glucose used by endothelial cells, respectively. This does not, however, necessarily negate an important role for the hexosamine biosynthetic pathway in cell physiology or function. Enhanced hexosamine biosynthesis, for example, has been reported to exert a variety of biological functions, including mediating insulin resistance in diabetes mellitus [7-15]. A recent report showed that intravenous infusion of glucosamine considerably reduced endothelium-dependent blood flow in hind limb femoral muscles of normoglycaemic rats [16]. This result implies impaired endothelial nitric oxide generation in glucosamineinfused subjects. We have recently provided direct evidence for the inhibition by glucosamine of nitric oxide synthesis in endothelial cells [21]. It is noteworthy that increasing extracellular concentrations of both glutamine and glucose results in decreased nitric oxide production by endothelial cells [18-20, 32, 33]. Because of the important role for nitric oxide in regulating vascular tone and blood flow [34], we suggest that the glucosamine-biosynthetic pathway mediates the inhibition of endothelial nitric oxide synthesis by hyperglycaemia and glutamine.

In summary, our study shows the presence of GFAT activity for glucosamine-6-P and UDP-GlcNAc synthesis in endothelial cells and the modulation of this pathway by hyperglycaemia and glutamine. This knowledge might pave a new path for elucidating the mechanism responsible for cardiovascular dysfunction in diabetes mellitus.

Acknowledgements. This research was supported by grants from the American Heart Association and the Juvenile Diabetes Foundation International and by Interdisciplinary Research grants from Texas A \& M University. G. Wu is an Established Investigator of the American Heart Association. We thank K. Kelly for her technical assistance and F. Mutscher for secretarial support.

\section{References}

1. Zalkin H, Smith JL (1998) Enzymes utilizing glutamine as an amide donor. Adv Enzymol Relat Areas Mol Biol 72: 87-144

2. Richards TC, Greegard O (1973) Distribution of glutamine hexosephosphate aminotransferase in rat tissues: changes with state of differentiation. Biochim Biophys Acta 304: 842-850

3. Marshall S, Bacote V, Traxinger RR (1991) Discovery of a metabolic pathway mediating glucose-induced desensitization of the glucose transport system. J Biol Chem 266: 4706-4712

4. McClain DA, Paterson AJ, Roos MD, Wei X, Kudlow JE (1992) Glucose and glucosamine regulates growth factor gene expression in vascular smooth muscle cells. Proc Natl Acad Sci USA 89: 8150-8154

5. Nerlich AG, Sauer U, Kolm-Litty V, Wagner E, Koch M, Schleicher ED (1998) Expression of glutamine:fructose-6phosphate amidotransferase in human tissues. Diabetes 47: $170-178$

6. Kolm-Litty V, Sauer U, Nerlich A, Lehmann R, Schleicher ED (1998) High glucose-induced transforming growth factor $B 1$ production is mediated by the hexosamine pathway in porcine glomerular mesangial cells. J Clin Invest 101: 160-169

7. Hawkins M, Barzilai N, Chen W et al. (1996) Increased hexosamine availability similarly impairs the action of insulin and IGF-I on glucose disposal. Diabetes 45: 1734-1743

8. Buse MG, Robinson KA, Gettys TW, McMahon EG, Gulve EA (1997) Increased activity of the hexosamine synthesis pathway in muscles of insulin-resistant $o b / o b$ mice. Am J Physiol 272: E1080-E1088

9. Baron AD, Zhu JS, Zhu JH, Weldon H, Maianu L, Garvey WT (1995) Glucosamine induces insulin resistance in vivo by affecting GLUT4 translocation in skeletal muscle. J Clin Invest 96: 2792-2801 
10. Hebert LF, Daniels MC, Zhou J et al. (1996) Overexpression of glutamine:fructose-6-phosphate amidotransferase in transgenic mice leads to insulin resistance. J Clin Invest 98: 930-936

11. Robinson KA, Weinstein ML, Lindenmayer GE, Buse MG (1995) Effects of diabetes and hyperglycemia on the hexosamine synthesis pathway in rat muscle and liver. Diabetes 44: 1438-1446

12. Robinson KA, Sens DA, Buse MG (1993) Pre-exposure to glucosamine induces insulin resistance of glucose transport and glycogen synthesis in isolated rat skeletal muscles. Diabetes 42: 1333-1346

13. Rossetti L, Hawkins M, Chen W, Gindi J, Barzilai N (1995) In vivo glucosamine infusion induces insulin resistance in normoglycemic but not in hyperglycaemic conscious rats. J Clin Invest 96: 132-140

14. Shankar RR, Zhu JS, Baron AD (1998) Glucosamine infusion in rats mimics the $\beta$-cell dysfunction of non-insulin-dependent diabetes mellitus. Metabolism 47: 573-577

15. Patti ME, Virkamaki A, Landaker EJ, Kahn CR, Yki-Jarvinen $H$ (1999) Activation of the hexosamine pathway by glucosamine in vivo induces insulin resistance of early postreceptor insulin signaling events in skeletal muscle. Diabetes 48: 1562-1571

16. Holmäng A, Nilsson C, Niklasson M, Larsson BM, Lönroth $P$ (1999) Induction of insulin-resistance by glucosamine reduces blood flow but not interstitial levels of either glucose or insulin. Diabetes 48: 106-111

17. Hecker M, Sessa WC, Harris HJ, Anggard EE, Vane JR (1990) The metabolism of L-arginine and its significance for the biosynthesis of endothelium-derived relaxing factor. Proc Natl Acad Sci USA 87: 8612-8616

18. Meininger CJ, Wu G (1997) L-Glutamine inhibits nitric oxide synthesis in bovine venular endothelial cells. J Pharmacol Exp Ther 281: 448-453

19. Cosentino F, Luscher TF (1998) Endothelial dysfunction in diabetes mellitus. J Cardiovas Pharmacol 32 [Suppl 3]: S54S61

20. Mitchell JA, Gray P, Anning PD, Woods M, Warner TD, Evans TW (2000) Effects of nitric oxide-modulating amino acids on coronary vessels: relevance to sepsis. Eur J Pharmacol 389: 209-215

21. Wu G, Haynes TE, Li H, Yan W, Meininger CJ (2000) Glutamine metabolism to glucosamine is necessary for glutamine inhibition of endothelial nitric oxide (NO) synthesis. Nitric Oxide: Chem Biol 4: 226-227
22. Wu G, Meininger CJ (1993) Regulation of L-arginine synthesis from L-citrulline by L-glutamine in endothelial cells. Am J Physiol 265: H1965-H1971

23. Wu G, Meininger CJ (1995) Impaired arginine metabolism and NO synthesis in coronary endothelial cells of the spontaneously diabetic BB rat. Am J Physiol 269: H1312-H1318

24. Weckbecker G, Keppler DO (1983) Separation and analysis of 4'-epimeric UDP-sugars by borate high-performance liquid chromatography. Anal Biochem 132: 405-412

25. Nakhooda AF, Like AA, Chappel CI, Murray FT, Marliss EB (1976) The spontaneously diabetic Wistar rat. Diabetes 26: $100-112$

26. Yki-Järvinen H, Vogt C, Iozzo P et al. (1997) UDP-Nacetylglucosamine transferase and glutamine:fructose 6phosphate aminotransferase activities in insulin-sensitive tissues. Diabetologia 40: 76-81

27. Steel RG, Torrie JH (1980) Principles and Procedures of Statistics. McGraw-Hill, New York

28. Wu G, Haynes TE, Li H, Meininger CJ (2000) Glutamine metabolism in endothelial cells: ornithine synthesis from glutamine via pyrroline-5-carboxylate synthase. Comp Biochem Physiol A 126: 115-123

29. Wu G, Majumdar S, Zhang J, Lee H, Meininger CJ (1994) Insulin stimulates glycolysis and pentose cycle activity in bovine microvascular endothelial cells. Comp Biochem Physiol C 108: 179-185

30. Yki-Jarvinen H, Daniels MC, Virkamaki A, Makimattila S, DeFronzo RA, McClain D (1996) Increased glutamine:fructose-6-phosphate amidotransferase activity in skeletal muscle of patients with NIDDM. Diabetes 45: 302-307

31. Oki T, Yamazaki K, Kuromitsu J, Okada M, Tanaka I (1999) cDNA cloning and mapping of a novel subtype of glutamine:fructose-6-phosphate amidotransferase (GFAT2) in human and mouse. Genomics 57: 227-234

32. Giugliano D, Marfella R, Coppola L et al. (1997) Vascular effects of acute hyperglycaemia in humans are reversed by L-arginine. Evidence for reduced availability of nitric oxide during hyperglycemia. Circulation 95: 1783-1790

33. Okuda Y, Kawashima K, Suzuki S et al. (1997) Restoration of nitric oxide production by aldose reductase inhibitor in human endothelial cells cultured in high-glucose medium. Life Sci 60: PL53-PL56

34. Ignarro LJ, Cirino G, Casini A, Napoli C (1999) Nitric oxide as a signaling molecule in the vascular system: an overview. J Cardiovasc Pharmacol 34: 879-886 